\title{
Universal dignity, justice and accountability: protection of human rights and dealing with atrocities
}

\author{
MOELOFSE
}

\begin{abstract}
The notion that human beings have rights as humans is part of the contemporary world and its politics. With respect to human rights, the United Nations (UN) plays a major role in promoting, protecting, and expanding internationally accepted rights through establishing several comprehensive agreements and mechanisms since 1945. Thus, on a global level, human rights and the violations thereof have become a legitimate concern of international society. However, there is a difference between declaring and practising human rights.

Consequently, political changes have occurred all over the world in recent years where several repressive regimes have been replaced with democratic or semi-democratic governments. In the process, these regimes are confronted with the question of justice and that accountability is due after atrocity. The widely held belief is that crimes against humanity must be addressed and perpetrators have to be called to account, while justice has to be determined.

The article will focus on what is understood by "human rights" and how the UN went about to guarantee human rights and eliminate the violations thereof by implementing a network of human rights instruments and mechanisms. The article will also indicate that, in practice, there are certain difficulties with the enforcement of these UN Conventions. The different options to be considered by countries in dealing with a violent legacy will be examined to explain why many transitional societies prefer to establish a truth commission.
\end{abstract}

Keywords: Human rights; United Nations; Conventions to promote and protect human rights; Human rights violations; Prosecutions; Blanket amnesty; Truth commissions.

Disciplines: History, Political science, Transitional justice, Human rights law.

\section{Introduction}

The United Nations (UN) has defined a broad range of internationally accepted human rights and has also established mechanisms to promote and protect these rights and help, as well as

Marietjie Oelofse is attached to the University of the Free State, Department of History, PO Box 339, Bloemfontein 9300. Tel: 051 401-2276. Fax: 051 444-5803. E-mail: oelofsem@ufs.ac.za. The author gratefully acknowledges the financial assistance of the National Research Foundation of South Africa in facilitating this research. Opinions expressed and conclusions arrived at, are the author's own, and are not necessarily to be attributed to the National Research Foundation. 
support governments in enforcing their responsibilities. ${ }^{1}$ This had led to the situation where human rights have, at present, a greater prominence in foreign policy than at any other time. However, the implementation of these mechanisms remains almost exclusively national. ${ }^{2}$ Thus, instead of being guardians of human rights, States have often become the violators of human rights.

As a result, the twenty-first century is characterised by the choices facing societies that emerged from a period of violence, as well as the process in which divided societies struggle to master a heritage of collective violence and severe gross human rights violations.

Confronted with processes and responses of how to deal with a past of human rights violations, the desire to know the truth of what happened, as well as to remember the past and to establish a clear break with the past, will influence the decisions. Knowing what really happened and untangling the web of lies and manipulations may constitute a fundamental role in "coming to terms" with the past. Here, acknowledgement in dealing with past wrongs that may lead to healing is considered. Justification is made on the grounds that in remembering the past, forgiveness and reconciliation may be considered only when a nation has confronted the full knowledge of the past.

When a period of authoritarian rule accompanied with atrocity ends, society as a whole must find a way to move forward, rebuilding shattered lives and recreate a liveable space of national peace, where former enemies reunite, as well as to secure these events in the past. In the comprehensive range of political transformations and within historical context, there is a reflection for a national desire for truth-telling and official truth-seeking. ${ }^{3}$

Furthermore, human rights advocates have been pressurising the UN that international human rights treaties must obligate governments to investigate and make public to victims and their families all that can be known and established about crimes against humanity. ${ }^{4}$

In dealing with a violent legacy, three options may be selected: prosecution, a blanket amnesty which results in national amnesia, or a process of setting up a truth commission. Especially since the Truth and Reconciliation Commission in South Africa (TRC), truth commissions as such have attracted world-wide attention and have gained ground. However, it must be noted that truth commissions are part of the broader field of transitional justice and are only one tool among others available to help societies to confront a violent past through a transitional justice process.

The article will focus on what is understood by "human rights" and how the UN went about to guarantee human rights and eliminate the violations thereof by implementing a network of human rights instruments and mechanisms. The article will also indicate that, in practice, there are certain difficulties with the enforcement of these UN Conventions, resulting sometimes in human rights violations. The different options to be considered by countries in dealing with a

1 United Nations, "Human rights", <http://www.un.org/rights/morerights.htm>, 2000, (accessed 30/3/2009).

2 J. Donnelly, Universal human rights in theory \& practice (second edition), pp. 34, 172.

3 P.B. Hayner, Unspeakable truths. Facing the challenge of truth commissions, p. 4.

$4 \quad$ Ibid., p. 106. 
violent legacy will be examined to explain why many transitional societies prefer to establish a truth commission.

\section{The evolution of global human rights}

On a global and regional level, there are numerous conventions in relation to various human rights where different states assert to these instruments and mechanisms while non-governmental organisations make its liturgy their aim. It is a fact that human rights and the violations thereof have become more and more prominent in international discourse. The twenty-first century is marking a new epoch for the invention of new and distinctive legal forms of response against mass violence and atrocities. ${ }^{5}$

What does it mean to have a right as a human being? Stewart claims that the term "human rights" is difficult to define and that no consensus exists as to what these rights should be. It seems as if the idea of human rights is not an obvious one. Habibi focuses on the term "rights" and define it as

protections or entitlements that individuals hold against other individuals, the state, or some other community. In turn, the rights conferrers have a corresponding obligation to non-interference or to enable the rights holders to exercise their rights. ${ }^{6}$

Human rights are described as

rights that we hold by virtue of the fact that we are human beings. ${ }^{7}$

For Stewart, human rights are regarded generally as those “

fundamental and inalienable rights which are essential for life and which the international community recognizes as belonging to all individuals by the very fact of their humanity. ${ }^{8}$

Consequently, human rights are seen as universal, thus transcending culture and place. It is categorical and without exception, which means that everyone has human rights and no one can take them away. Furthermore, these rights are inalienable, indefeasible, and indefatigable as every human being is of infinite worth and dignity and should be treated as an end and never as a means only. The primary qualification for holding human rights is to belong to the human race. ${ }^{9}$

5 M. Minow, Between vengeance and forgiveness. Facing history after genocide and mass violence, p. 1.

6 D.A. Habibi, "Human rights and politicized human rights: a utilitarian critique" in Journal of human rights 6, 2007, p. 6. See also R.J. Vincent, Human rights and international relations, pp. 7-9, where the author explains the idea of rights.

7 Habibi, p. 6.

8 N.F. Stewart, "International protection of human rights: the United Nations System" in The International Journal for Human Rights 12 (1), February 2008, p. 89.

9 Habibi, p. 7; Vincent, p. 10. 
Everyone has human rights by virtue of their humanity, which are based on an appeal to our human nature. Accordingly, human rights must be enjoyed not only universally, but also equally by all people, irrespective of race, gender or belief. It seems also that all basic human rights have three correlative duties which in turn will trigger each of these duties, namely, duties to avoid depriving, duties to protect from deprivation and duties to aid the deprived. ${ }^{10}$

Human rights are divided further into first-generation rights, namely civil and political rights, which include the right to life and liberty, freedom of thought and expression, and equality before the law. Second-generation human rights comprise economic and cultural rights in nature. These relate to the equal treatment of citizens such as the right to employment, healthcare, housing, and protection. Third-generation rights are not directly part of the Universal Declaration of Human Rights, but are consecutive instruments stated in multilateral declarations such as the Stockholm Declaration on Human Development (1972) and the Rio Declaration on the Environment and Development (1992). ${ }^{11}$

To violate the most basic human rights, is to deny individuals their essential moral entitlements, in other words, to treat an individual less than a human being as if he/she does not deserve respect and dignity. When any state or non-state actor breaches any part of the Universal Declaration of Human Rights, international treaties or other international human rights or humanitarian law, human rights violations occur. Abuse of human rights often leads to conflict resulting in human rights violations. These violations are monitored by the UN committees, national institutions, governments and various non-governmental organisations. ${ }^{12}$

The idea of human rights pre-dates the UN. However, modern international human rights law is a post-World War II phenomenon. During and after the Second World War, more focus was given to the protection of individuals and the guarantee of human rights. Human rights became a factor in public political debate. This tendency became reality when the founders of the UN responded to the severe human rights violations during the Second World War by giving universal and formal recognition to human rights in 1945 through the Charter of this organisation. ${ }^{13}$

The Preamble of the Charter of the United Nations declares:

... to reaffirm faith in fundamental human rights, in the dignity and worth of the human person, in the equal rights of men and women and of the nation large and small ....

10 Vincent, pp. 11, 13.

11 J. Akokpari, "Human rights and human security in Post-9/11 Africa" in J. Akokpari \& D.S. Zimbler (eds), Africa's human rights architecture, p. 69. Compare this also with Bryan Hehir's explanation that human rights legislation in international relations has moved through three stages in Harvard Law School Human Rights Program, Truth Commissions: a comparative assessment. An interdisciplinary discussion held at Harvard Law School in May 1996, p. 13.

\begin{tabular}{lll}
$\begin{array}{l}\text { Beyond Intractability, } \\
\text { http://www.beyondintractability.org/essay/human rights violations/, }\end{array}$ & 2007, & $\begin{array}{r}\text { violations", } \\
\text { (accessed }\end{array}$ \\
\hline $30 / 3 / 2009)$ &
\end{tabular}

13 T. Buergental, International human rights in a nutshell (second edition), p. 21; United Nations, "Fiftieth Anniversary of the Universal Declaration of Human Rights", <http://www.un.org/rights/50/broch.htm>, 1998, (accessed 30/3/2009). 
In this preamble, the states and peoples of the UN are committed to save succeeding generations from the scourge of war. Furthermore, the UN Charter imposes obligations upon members to protect human rights as set out in Article 1 of the Charter in the purposes of its organisation in

promoting and encouraging respect for human rights and for fundamental freedoms for all, without distinction as to race, sex, language or religion.

Article 13(1) of the Charter emphasises that, in all of this, the General Assembly shall initiate studies and make recommendations for this purpose. Articles 55, 56 and 59 of the UN Charter set the tone further for its members concerning legal obligations (even where applicable to initiated negotiations), to promote universal respect for and observance of human rights and fundamental freedoms. Again this notion is reflected in Article 76, where the international trusteeship system is set out. ${ }^{14}$

Thus, the UN takes as its purpose the promotion of respect for human rights and fundamental freedoms and the members pledge to take separate and joint action in cooperation with the UN to accomplish this goal. ${ }^{15}$

Through the Charter, the UN "internationalised" human rights by making it an international concern. A new era had begun with the commitment to promoting and expanding the ideals of human rights. However, the UN Charter does not define and specify what is meant by "human rights and fundamental freedoms" and does not establish any specific way to ensure implementation in member states. An effort had to be made in the following years by the UN to define and codify these rights. ${ }^{16}$

Over the following years, a network of human rights instruments and mechanisms would be developed to safeguard the primacy of human rights and to eliminate and confront human rights violations where they occurred. Following the Charter, a principal policy-making body for human rights within the UN system was established in 1946. This UN Commission on Human Rights reviewed human rights issues, develops and codifies new international norms and makes recommendations to Governments. ${ }^{17}$

This was followed by the General Assembly's adoption of the Universal Declaration of Human Rights (UDHR) on 10 December 1948. This Declaration remains the first pillar of twentieth century human rights law and remains the cornerstone of the universal human rights movement, as well as the best known and most cited human rights document in the world. ${ }^{18}$

The Declaration covers a comprehensive list of political, civil, economic, social, and cultural rights in 30 distinct and concise articles. For the first time the rights and freedoms of individuals were set forth in detail. It is built on the fundamental principle that human rights are based on

14 I. Brownlie (ed.), Basic documents on human rights (third edition), pp. 3-14; Buergenthal, pp. 23-26; Vincent, pp. 92-93.

15 Vincent, pp. 92-93.

16 Buergental, pp. 22-28.

17 Donnelly, pp. 129, 132-133; United Nations, "Fiftieth Anniversary ...”.

18 Donnelly, pp. 22-23. 
the "inherent dignity and equal and inalienable rights" of every person. This dignity, as well as the rights to freedom and equality deriving thereof, are undeniable and have been proclaimed "as the highest aspiration of the people". ${ }^{19}$

Although the Declaration was adopted as a resolution and does not have the binding force of a treaty, it has acquired universal acceptability. Notwithstanding, the Declaration played an important role in the adoption of a series of multilateral treaties, conventions and declarations concluded through the UN on human rights, and inspired human rights activism and legislation all over the world. ${ }^{20}$ Buergental emphasises the following view:

The Declaration ... is now considered to be an authoritative interpretation of the UN Charter ... it has joined the Charter as part of the constitutional structure of the world community. The Declaration, as an authoritative listing of human rights, has become a basic component of international customary law, binding all states, not only members of the United Nations. ${ }^{21}$

The Declaration gives equal importance to civil rights and political liberties (Articles 3 to 21), as well as to economic, social and cultural rights (Articles 22 to 27), and affords them the same degree of protection. ${ }^{22}$ The first two articles ${ }^{23}$ lay the
universal foundation of human rights: human beings are equal because of their shared essence of human dignity; human rights are universal not because of any State or international organization, but because they belong to all of humanity. The two articles assure that human rights are the birthright of every one, not privileges of a select few, nor privileges to be granted or derived. ${ }^{24}$

Article 28 to 30 adds to a larger protective framework in which all human rights are to be enjoyed universally. ${ }^{25}$

In addition to the human rights provisions of the UN Charter and of the Universal Declaration of Human Rights, the International Bill of Rights consists of the two International Covenants on Human Rights and the Optional Protocols to the International Covenant on Civil and Political

19 United Nations, "Universal Declaration of Human Rights. A United Nations Priority", <http://www.un.org/rights/HRToday/declar.htm>, s.a, (accessed 30/3/2009).

20 Stewart, p. 91; United Nations, "Fiftieth Anniversary ..."; United Nations, "Universal Declaration ...”.

21 Buergental, p. 37.

22 Centre for Human Rights, Human rights. A compilation of international instruments, Vol. 1, pp. 1-7.

23 Article 1: "All human beings are born free and equal in dignity and rights. They are endowed with reason and conscience and should act towards one another in a spirit of brotherhood". Article 2: "Everyone is entitled to all rights and freedoms set forth in this Declaration, without distinction of any kind, such as race, colour, sex, language, religion, political or other opinion, national or social origin, property, birth or other status". See Centre for Human Rights, p. 2.

24 Stewart, p. 92.

25 Centre for Human Rights, pp. 6-7; United Nations, "Universal Declaration ...”. 
Rights. ${ }^{26}$ These two International Covenants are the broadest legally binding human rights agreements negotiated under UN auspices. It includes the International Covenant on Economic, Social, and Cultural Rights (ICESCR ${ }^{27}$ and the International Covenant on Civil and Political Rights (ICCPR). ${ }^{28}$ Both Covenants were adopted in 1966 but only entered into force in 1976, making many of the provisions of the Universal Declaration effectively binding for States that ratified them. The Preambles and Articles 1, 2, 3 and 5 are virtually identical in both International Covenants. ${ }^{29}$

In the following years, several human rights treaties and declarations became part of the UN's aim to deal with specific types of human rights violations. Apart from the ICESCR and the ICCPR, there are more international human rights instruments, which include: Convention on the Prevention and Punishment of the Crime of Genocide (adopted by the UN in 1948 and entered into force in 1951); ${ }^{30}$ Convention Relating to the Status of Refugees (adopted by the UN in 1951 and entered into force in 1954); Convention relating to the Status of Stateless Persons (adopted by the UN in 1954 and entered into force in 1960); Convention on the Reduction of Statelessness (adopted by the UN in 1961 and entered into force 1975); Convention on the Elimination of All Forms of Racial Discrimination (adopted by the UN in 1965 and entered into force in 1969); ${ }^{31}$ Convention on the Suppression and the Punishment of

26 The Optional Protocol to the International Covenant on Civil and Political rights enables private parties, claiming to be victims of a violation of the Covenant, to file complaints with the Human Rights Committee. The second Optional Protocol aims at the abolition of the death penalty. See Centre for Human Rights, pp. 41-49; Buergental, pp. 48-51.

27 Economic and social rights include the right to work and for a just reward; the right to the enjoyment of just and favourable conditions of work; the right to form and join trade unions; the right to rest and leisure, and to periodic holidays with pay; the right to a standard of living adequate to health and well-being; the right to the enjoyment of the highest attainable standard of physical and mental health; the right to social security, including social insurance; the right to the protection of the family; the right to education; and the right to participation in the cultural life of a community. Vincent, p. 11.

28 Civil and political rights include the rights to life, liberty, security of the person, privacy and property; the rights to marry and found a family; the rights to fair trial; freedom from slavery, torture and arbitrary arrest; freedom of movement and to seek asylum: the right to a nationality; freedom of thought, conscience and religion; freedom of opinion and expression; freedom of assembly and association; and the right to free elections, universal suffrage and participation in public affairs. Vincent, p. 11.

29 Centre for Human Rights, pp. 8-40; United Nations, "Universal Declaration ...”.

30 The Convention declares that genocide, whether committed in time of peace or time of war, is a crime under international law for which the individual perpetrator is punishable. The Genocide Convention is considered as the centerpiece of international law that applies to the protection of rights of groups to exist as groups, either as minorities or majorities. Article 2 sets out the acts constituting genocide. Buergental, pp. 58-61; Brownlie, pp. 31-34; United Nations, "Convention on the Prevention and Punishment of the Crime of Genocide", <http://www.hrweb.org/legal/genocide.html>, 1997, (accessed 30/3/2009).

31 Racial discrimination is prohibited through this Convention. Article 1 defines racial discrimination as "any distinction, exclusion, restriction or preference based on race, colour, descent, or national or ethnic origin which has the purpose or effect of nullifying or impairing TD, 6(1), July 2010, pp. $113-138$. 
the Crime of Apartheid (adopted by the UN in 1973 and entered into force in 1976); $3^{32}$ Convention on the Elimination of All Forms of Discrimination against Women (adopted by the UN in 1979 and entered into force in 1981);33 Convention against Torture and Other Cruel, Inhuman or Degrading Treatment or Punishment (adopted by the UN in 1984 and entered into force in 1987); ${ }^{34}$ Convention on the Rights of the Child (adopted by the UN in 1989 and

the recognition, enjoyment or exercise, on equal footing, of human rights and fundamental freedoms in the political, economic, social, cultural or any other field of public life". Article 2(1)(d) also requires from each State to "prohibit and bring to an end, by all appropriate means, including legislation as required by circumstances, racial discrimination by any person, group or organization". Centre for Human Rights, pp. 66-79; Buergental, pp. 61-67; Office of the High Commissioner for Human Rights, "International Convention on the Elimination of All Forms of Racial Discrimination", <http://www.unhchr.ch/html/menu3/b/d_icerd.htm> s.a, (accessed 30/3/2009).

32 This Convention suppresses and punishes apartheid as it is proclaims as "a crime against humanity". It further declares all inhuman acts attributable to the policies and practices of apartheid "crimes violating the principles of international law". Centre for Human Rights, pp. 80-86; Buergental, pp. 67-68.

33 The Convention is often described as an international bill of rights for women. It defines what constitutes discrimination against women and sets up an agenda for national action to put an end to such discrimination. In its preamble, the Convention explicitly acknowledges that "extensive discrimination against women continues to exist". Discrimination against women is defined in Article 1 as "any distinction, exclusion, or restriction made on the basis of sex" that diminishes the "recognition, enjoyment or exercise by women of human rights and fundamental freedoms in the political, economic, social, cultural, civil or any other field". In Article 2 the State Parties undertake "to embody the principle of equality of men and women in their national constitutions or other appropriate legislation" and to adopt laws or other measures "including sanctions where appropriate, prohibiting all discrimination against women". CEDAW (the Committee on the Elimination of Discrimination against Women) also addresses a wide range of problems encountered by women in their struggle for equality. Centre for Human Rights, pp. 150-163; Buergental, pp. 68-72; United Nations, "Convention on the Elimination of All Forms of Discrimination against Women”, <http://www.hrweb.org/legal/cdw.html>, 1997, (accessed 30/3/2009).

34 The Convention defines 'torture' as "any act by which severe pain or suffering, whether physical or mental, is intentionally inflicted on a person for such purposes, inter alia, of "obtaining from him or a third person information or a confession" (Article 1(1)). This Convention covers torture inflicted by government officials, as well as by private individuals or groups whose conduct such officials encourage or tolerate. Thus, the Convention is designed to prevent and punish torture committed "by or at the instigation of or with the consent or acquiescence of a public official or other person acting in an official capacity". Article 8 states that the State Parties are required to treat torture as an extraditable offense. It is also notable that the Convention affirms that there are "no exceptional circumstances whatsoever" to justify torture and that no orders from superior officers or a public authority may be validly invoked as a justification. (Articles 2(2) and 2(3)). The UN declared 26 June as the annual International Day in Support of Victims of Torture. Centre for Human Rights, pp. 293-307; Buergental, pp. 72-76; Office of the High Commissioner for Human Rights, "Convention against Torture and Other Cruel, Inhuman or Degrading Treatment or Punishment", <http://www.unhchr.ch/html/menu3/b/h_cat39.htm>, s.a, (accessed 30/3/2009). See also J.H. Burgers and H. Danelius, The United Nations Convention against Torture. A handbook on the Convention against Torture and Other Cruel, Inhuman or Degrading Treatment of Punishment, 
entered into force in 1990); and International Convention on the Protection of the Rights of All Migrant Workers and Members of Their Families (adopted by the UN in 1990 and entered into force in 2003). Many of these conventions established a special commission or committee directed towards monitoring the treaty's provisions.

The universal principles of human rights were also implemented on a regional basis, as this was encouraged by the UN. These regions, notably in Western Europe, America and Africa, have in turn identified themselves as the local bearers of human rights institutions in their own areas. ${ }^{35}$

Western Europe took the lead in the regional guarantee of human rights with the European Convention on Human Rights and Fundamental Freedoms, which entered into force in 1953. This Convention sought to guarantee rights, as well as to state them. A commission and a court of human rights were established for this specific purpose. ${ }^{36}$ In America, the American Convention on Human Rights entered into force in 1978, where a commission and court, similar to those in Europe, were established. ${ }^{37}$ Under the auspices of the former Organisation of African Unity, the African Charter on Human and People's Rights entered into force in $1986 .{ }^{38}$

where the authors provide a comprehensive commentary on the convention, as well as its background in the context of other international efforts to the eradication of torture.

35 Vincent, p. 95.

36 The Council of Europe, a regional inter-governmental organisation founded in 1949 by a group of Western European nations, was committed to the protection of human rights and the preservation of individual freedom and democracy. The Council's human rights system has its legal source in two treaties, namely the European Convention of Human Rights, guaranteeing basic civil and political rights, and the European Social Charter, proclaiming a register of economic and social rights. The rights guaranteed by the Convention have been expanded by additional Protocols. According to Article 19 of the Convention two institutions were established, namely the European Commission of Human Rights and the European Court of Human Rights. Buergental, pp. 102-106; Council of Europe, "Convention of Human Rights and Fundamental Freedoms", <http://conventions.coe.int/Treaty/en/Treaties/Htm/0905. htm>, s.a, (accessed 30/3/2009).

37 The Organisation of American States (OAS) is a regional inter-governmental organisation that has established law and institutions to promote and protect human rights. Two distinct legal sources form part of the inter-American human rights systems: one is based on the Charter of the OAS and the other is based on the American Convention on Human Rights. The Convention also provides for the establishment of the Inter-American Commission on Human Rights and the Inter-American Court of Human Rights. The rights guaranteed by the Convention have been expanded by additional Protocols. Buergental, pp. 174-175, 194-195, 198; Department of International Law. Organization of American States, Washington D.C., "American Convention on Human Rights 'Pact of San Jose, Costa Rica", <http://www.oas.org/juridico/English/treaties/b-32.html>, s.a, (accessed 30/3/2009).

38 The African Charter on Human and Peoples' Rights is the regions principal human rights instrument and provides a system for the protection and promotion of human rights that is intended to function within the institutional framework of the former OAU (it was replaced in 2002 with the AU). According to Buergental the African Charter differs from the European and American Conventions on Human Rights in a number of aspects. For example, the African Charter promulgates not only rights but also duties, and the treaty is drafted in a form that allows the State Parties to impose very broad limitations and restrictions on the execution of the 
There are at present no Asian organisations or conventions to promote and protect human rights. Countries vary at large in their account of human rights protection and their approach thereto. Consequently, there are also no regional approaches or agreements on human rights for Oceania.

On 20 December 1993, the post of UN High Commissioner for Human Rights was created. The High Commissioner coordinates the UN human rights programme and promotes universal respect for human rights. According to Resolution 48/141 (1994) paragraph 4(f), the most important function of the UN High Commissioner is spelled out as

\section{to play an active role in removing the current obstacles and in meeting the challenges to the full realisation of all human rights and in preventing the continuation of human rights violations throughout the world. ${ }^{39}$}

Thus, this permits the High Commissioner to tackle any human rights problem and to be actively engaged in endeavours to prevent human rights violations. The activities with regard to human rights are coordinated by the Office of the High Commissioner for Human Rights in Geneva, where the Office services the UN Commission on Human Rights and most UN human rights treaty bodies. ${ }^{40}$

The Vienna Declaration and Programme of Action adopted by the World Conference on Human Rights in 1993 gave high priority to preserving the integrity of the Universal Declaration. It stresses the universal nature of human rights and the need to fight all forms of racism, discrimination, xenophobia, and other forms of intolerance. It also emphasises the rights of women, children, minorities, and indigenous people. Importantly the Vienna Declaration states, for the first time explicitly, that all organs, programmes, and specialised agencies of the $\mathrm{UN}$ system should have a central role in strengthening human rights. ${ }^{41}$

rights it proclaims. The Charter also places great emphasis on African historical tradition. Furthermore, the Charter makes provision for the establishment of an African Commission on Human and Peoples' Rights, which has promotional and quasi-judicial functions. The Protocol to the Charter on the Establishment of an African Court on Human and Peoples' Rights was adopted in 1998. In 2003 the Protocol to the Charter on the Rights of Women in Africa, was also adopted. Buergental, pp. 228-230, 239-240; Brownlie, pp. 551-566.

39 United Nations General Assembly A/RES/48/141, "High Commissioner for the promotion and protection of all human rights", <http://www.un.org/documents/ga/res/48/a48r141.htm>, s.a, (accessed 31/3/2009).

40 Buergental, pp. 95-97; Donnelly, p. 135.

41 The Declaration notes that: "All human rights are universal, indivisible, and interdependent and interrelated. The international community must treat human rights globally in a fair and equal manner, on the same footing, and with the same emphasis. While the significance of national and regional particularities and various historical, cultural, and religious backgrounds must be borne in mind, it is the duty of States, regardless of their political, economic and cultural systems, to promote and protect all human rights and fundamental freedoms." United Nations, "World Conference on Human Rights, Vienna, 14-25 June 1993. Vienna Declaration and Programme of Action", <http://www.unhchr.ch/huridocda/huridoca.nsf/(Symbol)/A.CONF.157.23.EN?openDoc>, 2000, (accessed 30/3/2009); United Nations, "Fiftieth Anniversary ..."; United Nations, "Universal Declaration ...". See also Office of the High Commissioner for Human Rights, 
This Declaration was further underlined by the United Nations Millennium Declaration in 2000 where the Heads of State and Government reaffirmed their commitment to the purposes and principles of the UN Charter. They also rededicated themselves to support all efforts and uphold respect for human rights and fundamental freedoms, as well as respect for the equal rights of all without distinction between race, sex, language, or religion. Certain fundamental values were underlined such as freedom, equality, and tolerance. Clause $\mathrm{V}$ of the Millennium Declaration elaborated on human rights, democracy, and good governance. ${ }^{42}$

In 1998, the international community met in Rome to adopt a treaty establishing the International Criminal Court (ICC) in The Hague. The ICC's purpose is to prosecute individuals accused of crimes against humanity, genocide, war crimes and aggression. The ICC's jurisdiction stretches to the states where the crimes are committed or the home states of the accused that have ratified the Rome treaty. Further, the ICC will only pursue cases after 1 July 2002 when it entered into force, and when states possessing jurisdiction are unable or are unwilling to prosecute. Thus, the ICC is to be complementary to national criminal jurisdiction. This court does not form part of the UN and is accountable to countries that ratify its statute. Its statute ensures against unwarranted prosecutions. The future aim of the ICC is to assist in ending impunity and deter potential war criminals. ${ }^{43}$

The ICC Preamble states clearly that

millions of children, women, and men have been victims of unimaginable atrocities which threaten the peace and well-being of the world.

It further affirms that these "serious crimes must not go unpunished" and is, therefore, determined to

\section{put an end to impunity for the perpetrators of these crimes and contribute to the prevention of such crimes. ${ }^{44}$}

Article 7 sets out certain acts that, when committed as part of a widespread or systematic attack directed against any civilian population, will constitute a "crime against humanity". ${ }^{45}$

"Five-year review of the implementation of the Vienna Declaration and Programme of Action", <http://www.unhchr.ch/html/50th/vdparev.htm>, s.a, (accessed 30/3/2009).

42 Office of the United Nations High Commissioner for Human Rights, "United Nations Millennium Declaration”, <http://www2.ohchr.org/English/law/millennium.htm>, 2007, (accessed 30/3/2009).

43 S. Turner, "The dilemma of double standards in U.S. human rights policy" in Peace \& Change 28(4), October 3003, p. 543; Office of the United Nations High Commissioner for Human Rights, "Rome statute of the International Criminal Court", <http://www2.ohchr.org/english/law/criminalcourt.htm>, 2007, (accessed 30/3/2009); Stewart, p. 100.

44 Office of the United Nations High Commissioner for Human Rights, "Rome statute ...".

45 See Article $7\left(\begin{array}{lll}1 & \&\end{array}\right)$ of the Rome Statute of the ICC for the list and explanations of acts that means 'crime against humanity'. Office of the United Nations High Commissioner for Human Rights, "Rome statute ...." 
Until 2006, the UN Commission on Human Rights (UNCHR) was the main organ in the UN for achieving the purpose of its Charter, namely to promote respect for human rights and make it a general part of the business of international society at large. Already in 2005, the former UN Secretary-General, Kofi Annan, argued for reforms:

[T] The Commission's ability to perform its tasks has been overtaken by new needs, and undermined by the politicization of its sessions and the selectivity of its work. We have reached a point at which the Commission's declining credibility has cast a shadow on the reputation of the United Nations system as a whole, and where piecemeal reforms will not be enough. ${ }^{46}$

He further called for the formation of a new

Human Rights Council that would be a society of the committed, an institution that is populated by governments that have a solid record of commitment to the highest human rights standards. ${ }^{47}$

The United Nations Human Rights Council, created at the 2005 World Summit, replaced the UNCHR on 15 March 2006. This Council has a mandate to promote and protect human rights around the globe and to investigate and address gross and systematic violations of human rights and make recommendations. Thus, the Council works in close cooperation in the field of human rights with a variety of governments, organisations, institutions, as well as civil society. ${ }^{48}$

Apart form the UN, various governmental and independent non-governmental organisations (NGOs) were established to deal with human rights. Since 1945, non-governmental organisations have contributed extensively to the UN's work on human rights. With this, human rights took on a "moral aura" for interpreting international humanitarian law and for judging nations. These organisations collect evidence and provide information of alleged human rights violations, highlighting these violations and contribute to the global protection thereof by applying pressure to enforce human rights laws. ${ }^{49}$

In essence, every UN body and specialised agency is involved, to some degree, in the protection of human rights. For the first time in history, the creation of a comprehensive body of human

46 J.H. Lebovic and E. Voeten, "The politics of shame: The condemnation of country human rights practices in the UNCHR" in International Studies Quarterly 50, 2006, pp. 861-862; L. Rahmani-Ocora, "Giving the emperor real clothes: the UN Human Rights Council" in Global Governance 12, 2006, p. 15.

$47 \quad$ Ibid.

48 United Nations High Commissioner for Human Rights, "Resolution Establishing the Council" in International Debates, 4(5), May 2006, pp. 137-139.

49 Habibi, p. 6. See also how Habibi criticizes in this article the leading organisations of the International Human Rights Movement that have lost sight of their own professed values and follow the politicised UN. Amnesty International, founded in Britain in 1961, remains with it 2.2 million members the world's largest organisation dedicated to the cause of human rights. Other non-governmental organisations focusing on human rights include: Human Rights Watch, International Federation of Human Rights, World Organisation Against Torture, Freedom House, International Freedom of Expression Exchange and Anti-Slavery International, to name but a few well-known NGOs. 
rights law, which provides the international community with a universal and internationally protected code of human rights, one to which all nations can subscribe and to which all people can aspire, is a great achievement. ${ }^{50}$ Kofi Annan publicly identified human rights as a

\section{cross-cutting issue and vital component of all aspects of the UN's work including} bumanitarian and peacekeeping efforts. ${ }^{51}$

The affirmation of the centrality of human rights to all UN programmes was further underlined by Annan, stating that:

\section{I fully agree ... on the centrality of human rights to United Nations peace activities and on the need to integrate human rights more effectively into prevention, peacekeeping, and peace-building strategies. ${ }^{52}$}

However, despite a growing awareness assisted by mass communications, of the importance and urgency for the respect of human rights, there are people around the world who, on a daily basis, suffer from some serious violation of their human rights. In practice, an immense gap exists between declaring and practising human rights. Conditions are not always created whereby society may enjoy these rights as set out by the UN.

In theory, the UN has the authority, ability, and action to respond effectively to human rights violations. Unfortunately, in practice there are certain gaps and difficulties that are encountered. The next step after acknowledging human rights should be the enforcement thereof. Herein lays the problem. Signature and ratification of conventions do not always imply allegiance to them. The absence of any real prospect of enforcement leads to doubt in the existence of human rights, as some governments, for variety of reasons, cannot keep and enforce these rights. Thus, ratification of international instruments may not even be a guide to the actual guarantee and commitment to human rights. ${ }^{53}$ It must be taken into account that international human rights accountability can only be translated into reality if authority, ability, and action are taken on a national level as the primary responsibility for implementing human rights lies with governments. ${ }^{54}$

According to Amnesty International, only a few countries do not commit significant human rights violations. The Amnesty International Report of 2008 (covering the period JanuaryDecember 2007), reveals the state of the world's human rights and how far the world has to go before people truly are free from fear and human rights violations. The Report indicates that the human rights promised in the Universal Declaration are far from being a reality for all the people in the world. Human rights violations still continue, while economic and social rights remain illusory for many people. Internal armed conflicts continue accompanied by abuses including

50 United Nations, "Human rights", <htpp://www.un.org/rights/morerights.htm>, 2000, (accessed 30/3/2009).

51 F.D. Gaer, "Human rights NGOs in UN peace operations" in International Peacekeeping 10 (1), Spring 2003, p. 80.

52 Ibid., p. 85.

53 Vincent, pp. 10, 99.

54 Stewart, pp. 102-104.

TD, 6(1), July 2010, pp. $113-138$. 
unlawful killings, torture and rape. Women's human rights are abused and been discriminated against. Consequently, the Report indicates that those responsible for human rights abuses often escape being held accountable. ${ }^{55}$

The challenge facing a society confronted with human rights violations is the manner in which it treats and faces these abuses. It must be done in such a way that the culture of impunity can be ended, resulting in accountability for past violations and securing a just future.

\section{To remember or forget? How to deal with atrocities of the past}

The question that needs to be answered about "what to do about the past" is how to deal with the atrocities of the past. It is important to deal with the past in the correct way, as one is also dealing with the future. The way one deals with the past impacts upon the shape of the future, while aiming at establishing a new political and moral order. It is, on the one hand, the political and ethical demand to confront past atrocities and on the other hand the desire to bury the past. In addition, international law allows an affirmative obligation on the part of states to investigate and punish gross violations of human rights. ${ }^{56}$

This issue of how to deal with the past raises serious questions. Can entire nations be considered guilty for the acts which were committed by a minority of the population and if so, where does it end? Who should ultimately be held responsible - the elite, the masses or both? Should the past be exhumed, preserved, apologised for and acknowledged? Whether and how do the people of a country want to remember and preserve their past - especially those who have suffered directly from past human rights abuses? How can the repetition of the atrocities of the past be prevented in the future? Once the damage has been done, how will it be repaired? How will societies heal? How can a balance be reached between too much forgetting and too much remembering? Questions arise concerning citizenship, responsibility, and guilt and ultimately, the question that needs to be answered: What would be the best way to deal with the past? ${ }^{57}$ To answer these questions, the debate is centred on whether truth should be the aim of accountability or whether justice should be the aim of accountability.

Kenneth Christie and Patricia Hayner argue that for many political scientists the notion of 'coming to terms with the past and dealing with it' is fundamental to the process of democratisation in post-authoritarian governments and states which appear to be undergoing traumatic changes. ${ }^{58}$ Christie indicates further that, with the aim of producing some form of

55 Amnesty International, Amnesty International Report 2008. The State of the World's Human Rights.

56 K. Christie, The South African Truth Commission, p. 63; A.M. Omar, "Foreword" in M.R. Rwelamira and G. Werle (eds), Confronting past injustices. Approaches to amnesty, punishment, reparation and restitution in South Africa and Germany, p. ix; Sunday Times, 12.6.1994, p. 20.

57 Christie, p. 39; Hayner, p. 267; Minow, p. 4; Sowetan, 9.6.1994, p. 8; Rapport, 26.6.1994, p. 23.

58 Christie, p. 63; Hayner, p. 11. 
collective memory of a traumatic history, the emerging democratic dispensation often sought to respond to the previous regime, typically by

dismantling their apparatus of control, punishing or giving amnesty to the old officials of those regimes, providing some form of reparation for survivors and victims commemorating their struggle and sacrifice through monuments, statues and the renaming of streets and avenues in their honour. ${ }^{59}$

Dealing with past injustices and human rights violations become both a political and ethical task. Thus, it becomes commonplace where the past needs to be "got over" and perhaps more crucially, needs to be seen to be "got over". ${ }^{60}$

Justice in the courts is usually the most prominent of demands in how to deal with past atrocities. It is argued that truth produced by trials is much more precise and trials produce better quality information as the information has been subjected to the rigours of the legal process and the rules of evidence. In other words, the highly developed rules of evidence, procedure, and proof that rule a trial ensure that a fact established in such a setting is more likely to be true. These rules are designed to reduce the possibility of a false positive to an acceptable level, but do not claim to eliminate such a risk entirely. ${ }^{61}$

Furthermore, the proponents of prosecutions believe that the population in general could benefit from a process of prosecutions as it helps to restore citizens' dignity after years of defencelessness, based on state terror. It may also be an efficient way of ascertaining the truth where the legal process ensures that the fact-finding will be thorough and reasonably impartial. Prosecutions will lead to a clear declaration of fault where the guilty will be punished or at least stigmatised. The prosecution process may also be useful in re-establishing the rule of law and providing a warning that future transgressions will not be excused. ${ }^{62}$

Those in favour of prosecutions for human rights violations, such as Professor Stephan Landsman, argue that prosecuting these human rights violations may enhance implicitly the chances of establishing the rule of law and signalling that no individual is outside the reach of legal accountability. In this sense and based on the theory that a society cannot forgive what it cannot punish, it is argued that prosecutions may be fundamental to the healing of social wounds

59 Christie, pp. 63-64.

60 Ibid., pp. 1, 64. Compare Christie's arguments for confronting the past with the reasons set out by Aryeh Neier in A. Boraine, et al., (eds), Dealing with the past. Truth and reconciliation in South Africa, p. 3.

61 R.C. Slye, "Amnesty, truth, and reconciliation: Reflections on the South African amnesty process" in R.I. Rotberg and D. Thompson (eds), Truth v. Justice. The morality of truth commissions, pp. 173-174.

62 N. Roht-Arriaza, "Introduction" in N. Roht-Arriaza, (ed.), Impunity and human rights in international law and practice, pp. 8-9. See also C.L. Sriram, Confronting past human rights violations. Justice vs peace in times of transition, pp. 7-10 for a discussion on the practical and ethical bases for punishment. 
caused by serious violations. ${ }^{63}$ The idea is to follow the Nuremberg trial paradigm that was used after the Second World War in the case of the defeated Nazis. People in favour of this option are of the opinion that all perpetrators of gross human rights violations should bear the full brunt of the normal judicial process. They argue that, technically, pardon or amnesty should not be extended to crimes against humanity. In their view these crimes constitute an international crime that requires some form of punitive retribution and retributive justice. ${ }^{64}$

In principle, Human Rights Watch is also opposed to granting immunity. They argue strongly that governments have a duty under international law to prosecute those guilty of gross violations of human rights. Likewise, Amnesty International points out that amnesty cannot be granted in cases of crimes against humanity, as well as torture and similar offences. ${ }^{65}$ A senior legal counsel at Human Rights Watch, Wilder Taylor, argues that

\section{as a matter of principle, this international obligation to investigate the truth allows no case- by-case exceptions. ${ }^{66}$}

However, trials are not always a workable model, taking into account several factors. Firstly, the very difficult question of "who would be put on trial?" has to be answered, which in turn could place an intolerable burden on an already strained judicial system and the resources available for such a process. Secondly, the time factor could also become a deterrent factor because airing details from cases of human rights abuse for too long could be distressing for many and too disruptive for the fragile peace and stability in a country. Lastly, a criminal court requires the evidence produced in a case to pass the most severe scrutiny, as well as investigation and to prove the case beyond reasonable doubt. In many cases, there is a lack of evidence because crimes were committed a long time ago. ${ }^{67}$

According to Hayner, the attempts to prosecute and punish those responsible for severe abuses under a prior regime, are the most difficult and have seen little success. Even if there is a functioning and trustworthy judicial system and no limits are placed on prosecuting the wrongdoers, which is rare, it is clear that domestic judicial systems cannot cope with the great

63 Minow, pp. 57-58. See also S.P. Huntington, "The Third Wave: Democratization in the late twentieth century" in N.J. Kritz (ed.), Transitional Justice. How emerging democracies reckon with former regimes, Vol. 1, pp. 68-69 for arguments in favour of prosecutions.

64 D.M. Tutu, No future without forgiveness, pp. 24, 27; Christie, pp. 14, 23; M. du Preez, "The price of truth" in The UNESCO Courier 52(12), December 1999, p. 24.

65 L.S. Graybill, "Pursuit of truth and reconciliation in South Africa" in Africa Today 44(1), January-March 1998, p. 114; M.R. Rwelamira, "Punishing human rights violations: Considerations in the South African context" in Rwelamira and Werle, p. 8; Sriram, p. 7; The Natal Witness, 13.12.1997, p. 7.

66 Hayner, p. 183.

67 Tutu, pp. 27-28; A. Boraine, A country unmasked. Inside South Africa's Truth and Reconciliation Commission, pp. 281-283; Christie, p. 53; J. Sarkin, "The trials and tribulations of South Africa's Truth and Reconciliation Commission" in South African Journal on Human Rights 12(4), 1996, pp. 618-619; Sriram, pp. 7-8; The Cape Times, 9.6.1994, p. 6. See also Huntington, pp. 68-69 for arguments opposed to prosecution, as well as M. Freeman, Truth commissions and procedural fairness, p. 10 outlining the reasons why criminal trials alone are not sufficient. 
demands of accountability for massive crimes. Thus, it is recognised that courts have limited reach. In addition, even successful prosecutions do not resolve the conflict and pain associated with past abuses. Furthermore, trials in international courts have also been limited. ${ }^{68}$ Martha Minow justifies these statements further by explaining that the reasons for relinquishing prosecution relate to the inherent limitations of trials, rather than to the limitations and failures of the nation's capacity to conduct trials. ${ }^{69}$

Paul van Zyl argues that trials are mostly about establishing guilt in specific instances, not about broader explanations or culpability. For him, trials have

limited explanatory value. They're about individual culpability, not about the system as a whole. A trial is not about our complicity. It makes it look they're guilty, not us. ${ }^{70}$

Lastly, Tina Rosenberg adds:

Trials that seek to do justice on a grand scale risk doing injustice on a small scale; their goal must not be Justice but justice bit by bit by bit. Trials, in the end, are ill suited to deal with the subtleties of facing the past. ${ }^{71}$

Furthermore, it is no simple matter to obtain a conviction in a court of law. A strong possibility is that the accused may be found not guilty because of a lack of evidence. This can be a set-back for those wanting prosecutions. The Malan trial especially, raised questions over the capacity and effectiveness of the criminal trials system in South Africa. During 1996 former Minister of Defence, Magnus Malan and nineteen others were accused of planning and carrying out a massacre in January 1987 of thirteen people in KwaMakhutha in the former hocymeland of KwaZulu, now KwaZulu-Natal. The murder happened when a hit-squad attack was carried out on the home of anti-apartheid activist Victor Ntuli. After a difficult trial, all defendants were acquitted. The case collapsed because of a lack of evidence linking Malan directly to the killings. Since the accused was a former state employee, the state was obliged to cypay the costs of the legal defence. The costs of this seven-month trial exceeded R12 million. ${ }^{72}$ This is underlined by Samuel Huntington:

Do not attempt to prosecute authoritarian officials for human rights violations. The political costs of such efforts will outweigh any moral gains. ${ }^{73}$

68 Hayner, pp. 11, 12, 14, 251. See Hayner, pp. 88-89 for the many reasons why so few trials of rights abuses take place. See also J. Tempelhoff, "Menseregte, boetedoening en die kultuurhistoriese toe-eieningsproses" in P.H. Kapp (ed.), Die Suid-Afrikaanse verlede en die skuldvraagstuk. Verslag van ' $n$ simposium oor die Afrikaanse geskiedskrywing en die toewysing van skuld, pp. 6-7.

69 Minow, p. 58.

70 Hayner, p. 101.

71 Minow, p. 51.

72 B. Hamber and S. Kibble, From truth to transformation, The Truth and Reconciliation Commission in South Africa, p. 8; Hayner, p. 101.

73 A. Boraine, "Introduction" in Boraine, et al., (eds), p. xvi. 
A dilemma with prosecution that needs to be considered by transitional states is the fact that it could lead to political violence and/or civil war, which could weaken an already vulnerable democratic system. In other words, it may destabilise a fragile transitional government resulting in prolonged political instability or even a return of dictatorship. ${ }^{74}$ Carlos $S$. Nino warns that the

consequences of attempting to punish all or some of those responsible for human rights violations may be dangerous for the stability of the democratic regime and ultimately for the preservation of those very human rights in the future. ${ }^{75}$

On the other hand, there are those who oppose the trial option and suggest that a country should rather let bygones be bygones, forget and bury the past and move on, expressing a desire to turn the page and focus on a new future. This option makes provision for a blanket or general amnesty. ${ }^{76}$

For those who want to leave the past alone, it is a case of

No, we do not want to enter into the morass of conflict, hatred, and pain. We want to focus on the future, for now, the past is too much part of the present for us to examine its details. For now, we prefer silence over confrontation, over renewed pain. While we cannot forget, we would like to pretend that we can. ${ }^{77}$

For some people, this option is not so much ignoring the atrocities of the past, but rather of concern for a newly emerging democracy and a way to protect it. To point to the guilty by digging up the details of past atrocities could aggravate the situation it sought to address and lead to more pain and further divisions in society. By dwelling on the past, a deeply divided society will be unable to overcome its divisions and move forward. In other words, official investigations may do more harm than good. ${ }^{78}$ Apart from these arguments, there is strong criticism against this option, which is, in effect, a call for collective amnesia.

Minow argues strongly that it is wrong to do nothing and that

dwelling in the frozen space of inability and incapacity is unacceptable, unresponsive to victims, unavailing to the waiting future. ${ }^{79}$

Archbishop Desmond Tutu states that, if the past is not recognised and kept quiet or lied about, it is "embarrassingly persistent, and will return and haunt us unless it has been dealt with

74 Christie, pp. 62-63; Roht-Arriaza, "Introduction" in Roht-Arriaza, (ed.), p. 9; The Cape Times, 13.2.1995, p. 2.

75 Boraine, "Introduction" in Boraine, et al., (eds), p. xvi.

76 Tutu, pp. 30-31; Boraine, p. 4; K. Asmal, "Coping with the past. A truth commission for South Africa" in Mayibuye, February 1994, p. 27. See Tina Rosenberg's criticism on this kind of reconciliation in T. Rosenberg, "Reconciliation and amnesty - Latin America" in Boraine, et al., (eds), pp. 66-68.

77 Hayner, p. 185. See also Hayner, pp. 185-186 where the author sets out the four elements that seem to be common in certain countries for a lack of desire to formally establish the truth.

78 Sarkin, p. 620; Roht-Arriaza, "Introduction" in Roht-Arriaza, (ed.), p. 8.

79 Minow, p. 4. 
adequately. Unless we look the beast in the eye, we will find that it returns to hold us hostage." 80 Judge Richard Goldstone agrees, stating that:

It is a recipe for national discontent and almost certainly will result in past abuses being repeated. ${ }^{81}$

There are examples of countries that made the choice for the option of simply ignoring the legacy of past crimes. For example, in Mozambique there has been almost no attention given to the accountability for past crimes and the accepted belief is that the

less we dwell on the past, the more likely reconciliation will be. ${ }^{82}$

However, according to Richard Carver, African rights expert, several countries in Africa have suffered by making such a choice with distinct negative long-term consequences from failing to come to terms with the crimes of the past. He suggests different ways to address and document the past, not necessarily through a truth commission only, but as long as there are always some form of truth-telling processes. ${ }^{83}$

Thus, despite calls for a process of amnesia, emphasis is placed rather on the necessity of remembering the past. Philosopher George Santayana explains it as follows:

Those who cannot remember the past, are condemned to repeat it. ${ }^{84}$

Richard von Weizsacker, former President of West Germany, goes further:

Whoever closes his eyes to the past becomes blind to the present. Whoever does not wish to remember inhumanity becomes susceptible to the dangers of new infection. ${ }^{85}$

Archbishop Desmond Tutu, chairperson of the South African Truth and Reconciliation Commission, explains that

unless our past was acknowledged and dealt with adequately, it could blight our future. ${ }^{86}$

Furthermore, for Kader Asmal the danger of not dealing with the past lies in the fact that we are thereby ripping the foundations of justice from beneath new generations. ${ }^{87}$

80 Tutu, pp. 30-32.

81 Sunday Times, 17.4.1994, p. 3.

82 Hayner, pp. 186-195.

83 Hayner, p. 184. See also B. Baker, "Twilight of impunity for Africa's presidential criminals" in Third World Quarterly 25(8), 2004, pp. 1487-1500 where the author examines the degree to which changes in international law, international judicial institutions and public opinion since the end of the Cold War have contributed to changes in the treatment of African tyrants who have been accused of crimes against humanity.

84 Tutu, p. 32.

85 Boraine, p. 366.

86 Tutu, p. 32. 
For Patricia Hayner, the inevitable question with which any country with past atrocities is confronted is whether a society can build a democratic future on a foundation of blind, denied, or forgotten history. ${ }^{88}$

If all the arguments are taken into account, it seems that criminal trials may be unfeasible and sometimes practically impossible and that blanket amnesty is unacceptable. It is then that a third option may be considered, where a truth commission would be the "middle-road" between the alternatives of pardon or prosecution and blanket amnesty or national amnesia.

In evaluating truth commissions in general and their role against a process of prosecution, Minow comes to the conclusion that truth commissions are not a second best alternative to prosecutions. According to her assessment of these two processes, truth commissions

\section{emphasize the experiences of those victimized; the development of a detailed historical record; and the priority of healing for victims and entire societies after the devastation to bodies, memories, families, friendships, and politics caused by collective violence. A truth commission could generate the evidence to support prosecutions. Or, when the fullest accounts and participation are sought in a nation marked by deep and historic divisions, a truth commission represents a potential alternative to prosecutions. ${ }^{89}$}

Allen indicates that recognition is indeed the business of law and criminal justice, as well as of truth commissions. The recognition afforded by truth commissions should serve as a complement and auxiliary to legal recognition. ${ }^{90}$ Kiss accentuates these arguments, clarifying that truth commissions have demonstrated convincingly that it is not just a "second best" process to past abuses. On the contrary, truth commissions can provide a much fuller account of human rights violations of the past and establish greater accountability among perpetrators than prosecutions are able to do realistically. ${ }^{91}$

Thus, trials focus more closely on identifying individual legal responsibility for specific crimes and punishing those found guilty. Truth commissions have no power to initiate trials and generally investigate and report. Courts and truth commissions may work with some of the same

87 A. Krog, Country of my Skull (second edition), p. 268. See also Boraine, p. 4 where he quotes Lev Tolstoy from Cathleen Smith's book Remembering Stalin's Victims, where her argument follows the same lines: "People say: why recall the past? What is the good of remembering what has been swept away? What is the good of irritating the nation? How can one ask such questions? If I suffered from a serious and dangerous disease and recovered or was cured from it, I would recollect the fact with joy. I would be disturbed by it only if I was still ill or if I'd taken a turn for the worse and wanted to deceive myself".

88 Hayner, p. 5.

89 Minow, p. 90. See also how this author sets out twelve more overlapping goals/aspirations with truth commissions in Minow, pp. 87-88.

90 J. Allen, "Between retribution and restoration: Justice and the TRC" in South African Journal of Philosophy 20(1), 2001, p. 29.

91 E. Kiss, "Moral ambition within and beyond political constraints: Reflections on restorative justice" in Rotberg and Thompson (eds), p. 91. 
material in focusing on describing the broad pattern of events, and commissions may make judicial-like decisions, but their goals, structures, and powers are contrary to one another. ${ }^{92}$

Boraine and Hayner argue that there are compelling reasons for the establishment of a truth commission that might contribute to justice. They set out certain points to be considered. The past cannot be ignored as it could make reconciliation even more difficult; for a forgiveness process, it is important to know what evil is being forgiven and who caused it; if dignity is to be restored to victims, knowledge of these violations have to be made known to the public; to establish an accurate record of a country's past and thus reclaiming a country's history and to open it for public review; to compensate victims, there must be knowledge and details of violations; knowledge of the truth must also be acknowledged officially by the state and people of a country; to contribute to accountability for perpetrators; to outline institutional responsibility and recommend reforms; if victims do not believe that their violations have been acknowledged and feel that justice will never be done, private acts of vengeance and retribution may follow; appraising the role of the courts as a whole in the system of repression and analysing what needs to change; promoting the rule of law and fulfilling international obligations. ${ }^{93}$

Ratner and Abrams are of the opinion that, while truth commissions as such may not provide as rigorous a determination of, or as serious a punishment for an individual's culpability as with prosecutions, in many cases it represents the best or only alternative. Truth commissions as a form of accountability may serve as valuable precursors or complements to criminal trials. ${ }^{94}$

Thus, many transitional societies choose a truth commission for a variety of reasons. It seems as if it has emerged as a popular tool for dealing with a legacy of human rights abuses in postconflict situations. Such a truth body may provide a more comprehensive record of a contested past, rendering an authoritative account of a specific period and/or of a specific regime, while determining the central causes of the violence and violations. In the end, such a commission of truth may make recommendations to prevent the future repetition of human rights violations. Although the focus is on human rights violations that occurred, truth commissions in general have very different aims, mandates, perceptions and resources available, as well as approaches to the kind of "truth" they are searching for. This has a definite influence on a commission's activities and on the end report and findings.

Consequently, if truth commissions are empowered efficiently, they can assist to accomplish some of the state's obligations under international law to answer to human rights violations. A truth commission could be the "bridge-building process", leading the nation away from a divided

92 Hayner, p. 88. See Freeman pp. 71-86, where the author debates about the significant differences and similarities between courts and truth commissions.

93 Boraine, pp. 33-34; Hayner, pp. 24-31, 102-106; Sunday Times, 17.4.1994, p. 3; The Cape Times, 8.6.1994, p. 8; Die Volksblad, 5.7.1994, p. 7. Compare also these arguments of Boraine with K. Asmal et al., Reconciliation through truth. A reckoning of Apartheid's criminal governance (second edition), pp. 10-11,28, where the authors provide a detailed layout of how a process of collective memory will in turn, move people towards a number of crucial goals. See also Freeman, pp. 37-40 setting out in detail the perceived advantages and disadvantages of truth commissions.

94 S.R. Ratner and J.S. Abrams, Accountability for human rights atrocities in international law. Beyond the Nuremberg legacy, p. 193. 
past to promoting a future based on peace and stability, the recognition of human rights and dignity, as well as national unity.

To date, most truth commissions have been established in Latin America and Africa. The nature of political violence in Latin America and Africa differs. In the former it is usually between right and left political sectors, with the military and security forces who have engaged in severe, violent repressive tactics. In Africa, political violence is in the form of conflict between ethnic 'tribal', social and religious groups. Here the violent conflict is often the result of the deliberate manipulation of group identities by political leaders. ${ }^{95}$

A brief overview of certain truth commissions that have been created in specifically Latin America and Africa will be included to accentuate the processes, methods, successes and failures of some of these more well-known truth commissions.

On 28 October 1982 the first Latin American truth commission was created in Bolivia, a few days after the return to democratic rule. Although they were able to locate some of the remains of missing people, no cases were definitively investigated. Difficulties such as limited financial support from the government, a lack of sufficient resources and political support, led to an incomplete process. After three years the commission disbanded without producing a final report. ${ }^{96}$

Argentina's truth commission was the first from the 1980s onwards to hold trials involving human rights violators. Argentina moved to a democratic rule in 1983 as the military retreated from power. The Argentines wanted to create a commission to investigate the violence of the seven-year military regime from 1976-1983. Through the "National Commission on the Disappeared", 8960 people who had disappeared were documented and a list of 365 former torture centres were reported and published. However, though the commission submitted more than 1800 cases for prosecution, justice was limited. From the previous military juntas that had ruled Argentina, nine members were prosecuted and five were convicted. When Carlos Saul Menem succeeded as president in 1989, he exonerated the five junta members who had already been convicted, as well as officers awaiting trial. ${ }^{97}$

The parliament of Uruguay created the "Investigative Commission on the Situation of 'Disappeared' People and its Causes" in April 1985, following eleven years of military rule. After seven months the commission reported and provided evidence on 164 disappearances and the involvement of the Uruguayan security forces, which was handed to the Supreme Court. However, much more common than disappearances, was torture and illegal imprisonment. The limited mandate of the commission prevented it from officially investigating and documenting

95 P.B. Hayner, "Fifteen truth commissions - 1974 to 1994: A comparative study" in Human Rights Quarterly 16(4), 1994, pp. 653-654.

96 Ibid., pp. 613-614; Hayner, Unspeakable truths ..., pp. 52-53.

97 Hayner, Unspeakable truths ..., pp. 33-34; Hayner, "Fifteen Truth Commissions ...", pp. 614-615; C. Smulovitz, "Commissions of truth and reconciliation - Argentina" in A. Boraine and J. Levy (eds), The healing of a nation?, pp. 56-57; J. Malamud-Goti, "Punishing human rights abuses in fledging democracies: The case of Argentina" in N. Roht-Arriaza, (ed.), pp. $161-170$ 
these practices. It is self-evident that a truth commission's mandate cannot exclude abuses that represent a large portion of the victims experiences, if it aims to be successful. ${ }^{98}$

In Chile, General Augusto Pinochet overthrew the civilian government in September 1973, brutally repressing all opponents and ruled Chile for seventeen years. President Patricio Aylwin assumed the presidency in March 1990 and established the "National Commission on Truth and Reconciliation". Within nine months the commission thoroughly investigated the 2920 cases within its mandate. The final report of 1800 pages received wide recognition from the public and especially from human rights organisations. However, there was no real condemnation of the role of the top leadership (i.e. General Augusto Pinochet). The reason for this lay in Pinochet's action in 1978 when he instituted an amnesty law, which barred prosecution for almost all human rights crimes that occurred after he had taken control. The commissioners further refused to reveal the names of the perpetrators and no attempt was made to prosecute individuals. Another commission, the "Reconciliation and Compensation Corporation" was established in 1990 to further investigate the abuses under the Pinochet regime, 1972-1990. A report published in 1996 found a further 899 cases of people who disappeared or died, which brought the total number of victims of political repression in Chile to $3197 .{ }^{99}$

The discussed truth commissions from Latin America tended to be quite substantial affairs, where each country had different responses to its transitional process and the quest for justice, depending on local governing factors and dynamics. Significantly, these Latin American truth commissions interacted and affected one another by addressing the injustices of the past.

Many of the truth-seeking bodies in Africa have tended to be smaller, less successful and sometimes less prominent. This is often the result of limited resources in the form of funds and staff. Some truth commissions in African countries are also faced with political bias and/or ethnic or group-identity antagonism.

Uganda went through two government sponsored truth commissions. The first commission came into being in 1974 in response to the increasing public pressure to investigate the accusations of disappearances at the hands of military forces during the first years of the Idi Amin government. The commission faced considerable practical difficulties and operated in an unfavourable political climate. The commission had minimum impact on the practices of the government of Amin and abuses by his forces increased considerably in subsequent years. The conclusion was that the commission was set up without any political will or responsibility for real change in human rights practice or policy. Twelve years later, in 1986 a second Commission of Inquiry was established to investigate human rights violations from 1962 to 1986. Major funding constraints

98 Hayner, Unspeakable truths ..., pp. 53-54; Hayner, "Fifteen Truth Commissions ...", pp. 616-617; L. Weschler, "Acknowledgement, truth \& justice - Uruguay" in Boraine, et al., (eds), pp. 41-46.

99 Hayner, Unspeakable truths ..., pp. 35-38; Hayner, "Fifteen Truth Commissions ...", pp. 621-623; M. Popkin and N. Roth-Arriaza, "Truth as justice: Investigatory commissions in Latin America" in Law and Society Inquiry: Journal of the American Bar Foundation 2, 1995, pp. 84-86; J. Correa, "Dealing with past human rights violations: The Chilean case after dictatorship" in Notre Dame Law Review 67, 1992, pp. 1455-1485.

TD, 6(1), July 2010, pp. $113-138$. 
limited and slowed the work of this commission, but a report was published in 1995, after nine years of investigation. ${ }^{100}$

Rwanda presented an altogether new truth commission model. The commission was funded and entirely sponsored by international non-governmental organisations. Although the government did not hinder the investigation during 1993, the government forces began killing in the days after the commission left the country and murdered an estimated 300-500 people. The final report was positively received in Rwanda and internationally. However, the Rwandan government reacted by launching a publicity attack on the rebels to make known their human rights violations. After this Commission, Rwandans engaged in 1994 in the fastest recorded genocide in history. This time the International Criminal Tribunal for Rwanda (ICTR) was authorised through the UN Security Council resolution 955 in November 1994, to prosecute acts of genocide, crimes against humanity and violations of the Geneva Convention that were committed between January and December $1994 .{ }^{101}$

A commission of inquiry was established in 1985 in Zimbabwe. The aim was to investigate the killing and governmental repression of an estimated 1500 political dissidents and other civilians in the Matabeleland region of the country. The commission worked under the authority of the president and was presided over by a Zimbabwean lawyer. After several months of investigation, a report was submitted directly to the president. To date, the report has not been made public by the government and no one outside the government has seen it. ${ }^{102}$

From the examples used, it is clear that human rights investigations vary remarkably, both in their political context and in their legal composition, as well as in their specific investigatory mandates and powers. It is self-evident that procedures and models which are appropriate at a specific time and place will not necessarily be appropriate for another country. Each country must shape a process of transition out of its own historical, political and cultural context. It was against these examples that South Africa took certain guidelines in the 'truth recovery' from former commissions, incorporated lessons from these commissions, but used them even more as warnings.

With the establishment of a truth commission, South Africa had to balance the requirements of justice, stability, peace, the restoration of dignity to victims, accountability and reconciliation. Means of reaching this would be to institute a commission, not on the grounds of vengeance or retribution, but one that may serve a reconciliatory, nation-building function. Thus, there was decided upon a unique truth commission for South Africa with the granting of amnesty to individuals, in exchange for full disclosure of the truth relating to the crime for which amnesty

100 Hayner, Unspeakable truths ..., pp. 51-52; Hayner, "Fifteen Truth Commissions ...", pp. 611-613; 618-620; R. Carver, "Called to account: How African governments investigate human rights violations" in African Affairs 89(355), pp. 397-400, Christie, p. 62.

101 Hayner, "Fifteen Truth Commissions ...", pp. 629-632; L.S. Graybill, "Pardon, punishment, and amnesia: Three African post-conflict methods" in Third World Quarterly 25(6), 2004, pp. 1120-1124; L. Graybill and K. Lanegran, "Truth, justice, and reconciliation in Africa: Issues and cases" in African Studies Quarterly 8(1), Fall 2004, pp. 8-9.

102 Hayner, Unspeakable truths ..., p. 55; Hayner, "Fifteen Truth Commissions ...", pp. 617-618; R. Carver, "Zimbabwe: Drawing the line through the past" in Roht-Arriaza, (ed.), pp. 258269. 
was being sought. It would also give an opportunity to ordinary people to tell their stories, allowing them to remember and empowering them in the process. In the end, especially from the victim's point of view, it seems as if the Truth and Reconciliation Commission of South Africa (TRC) endeavour was important and necessary. With its thorough and far-reaching investigations and inquiries, the TRC is described as the largest survey of human rights violations conducted anywhere in the world. The TRC was arguably the most ambitious to date and has been used as an example in many parts of the world as a new model for confronting a tormented and divisive history.

However, the existence of a truth commission is no assurance that the repetition of human rights abuses will necessarily deter future occurrences thereof. It also does not necessarily indicate a commitment to real change. Truth commissions as such should not be perceived as something of a panacea. At least the intention of most truth commissions is to reduce the possibility of the reoccurrence of these atrocities in the future. The hope exists that, with the publishing of an honest, accurate record of the violence, a society will learn from its past, and its more knowledgeable citizens will recognise the signs and prevent any future abuses, especially where specific recommendations for reform form part of a truth commission's final report and contributions to constructive changes for the future can be made.

It is true that truth commissions are not perfect. Many times it is a high risk exercise in the political history of a country. However, one cannot ignore the fact that truth commissions contribute to the cause of justice and the protection and promotion of human rights. The functions performed by truth commissions focus on the promotion of a just, democratic and open society and they endeavour to restore the collective dignity of a state and its people. This finds an echo in international humanitarian law.

\section{Conclusion}

It cannot be denied that over the years the UN has intensified its efforts to protect and promote human rights by assisting Member States and monitoring human rights violations. The world has come a far way since 1945. However, the prime responsibility for implementation and enforcement of these human rights instruments as laid down by the UN, remains with governments.

No clear answer is possible as to which is the better way to deal with atrocities: either retributive or restorative justice. Each country is different and an approach must be sought that will suit the specific situation. This requires a case-by-case, country-by-country analysis where competing interests should be taken into account before making choices. The particular context and the purposes and aims should be checked and balanced against the advantages and disadvantages of both forms of justice. Nevertheless, being more thorough, revealing and in a sense successful, truth commissions may provide useful cases for analysis as catalysts of justice in specific circumstances of transitional justice.

It must be realised that achieving justice with accountability is a long and difficult process. Truth commissions are by no means perfect, because the stakes in dealing with the past and settling accounts are remarkably high and seldom result in an adequate satisfactory conclusion accepted 
by all. At least transitional justice processes, including truth commissions, may make a valuable contribution to justice and democracy, as well as history. 